\title{
MAKNA DIBALIK PESAN POLITIK KEBANGSAAN PRESIDEN JOKOWI (Analisis Wacana Kritis Fairclaugh Terhadap Pernyataan Sikap Presiden Joko Widodo Menanggapi Kerusuhan Rasial di Papua dan Papua Barat)
}

\author{
Oleh: \\ Dr. Cosmas Gatot Haryono, S. Sos., M. Si. \\ Djunaedi Setyawan, S.I. Kom, M. I. Kom \\ Email:cgharyono@gmail.com \\ Dosen Program Studi Ilmu Komunikasi Universitas Bunda Mulia, Jakarta
}

\begin{abstract}
Abstrak
Penelitian ini bertujuan untuk mencari makna yang ada di balik pernyataan sikap Presiden Joko Widodo ketika menanggapi kerusuhan rasial yang menimpa masyarakat Papua dan Papua Barat beberapa waktu yang lalu. Pidato pernyataan sikap Jokowi tersebut menimbulkan pro dan kontra karena dianggap menyederhanakan persoalan yang terjadi. Aksi demo rusuh yang berujung pada kerusuhan rasial sendiri terjadi diberbagai daerah Papua bukan hanya dikarenakan adanya penangkapan mahasiswa papua oleh Polrestabes Surabaya saja, melainkan karena banyaknya berita dan informasi yang kurang bisa dipertanggung jawabkan bertebaran di media sosial yang sekarang ini menjadi bagian dari kehidupan masyarakat Indonesia. Peneliti menganalisis pidato Presiden tersebut dengan menggunakan analisis wacana kritis Norman Fairclough. Hasilnya menunjukkan bahwa presiden mewacanakan persoalan kesejahteraan yang tidak dinikmati masyarakat Papua dan Papua Barat sebagai biang keladi dari kerusuhan rasial yang terjadi. Pernyataan tersebut terlihat dimanfaatkan sebagai pembenaran untuk program-program Pemerintahan Jokowi di Papua dan Papua Barat, termasuk tentang infrastruktur karena program itulah yang diyakini akan mempercepat kesejahteraan masyarakat Papua dan Papua Barat.
\end{abstract}

Kata Kunci: Analisis Wacana Kritis, Kerusuhan rasial, dan Pesan Politik

\begin{abstract}
This study aims to find the meaning behind the statement of President Joko Widodo about racial riots that befell the people of Papua and West Papua some time ago. The speech of Jokowi's statement raises the pros and cons because it is considered to simplify the problems that occur. Riot demonstrations that led to racial riots occurred in various regions of Papua not only because of the arrest of Papuan students by the Surabaya Polrestabes, but because of the many unaccountable news and information that are scattered on social media that are now part of Indonesian people's lives. Researchers analyzed the President's speech using Norman Fairclough's critical discourse analysis. The results showed that the president discussed welfare issues that were not enjoyed by the people of Papua and West Papua as the culprits of the racial riots that occurred. The statement was seen as being used as a justification for Jokowi's Government programs in Papua and West Papua, including on infrastructure because the program was believed to accelerate the welfare of the people of Papua and West Papua.
\end{abstract}

Keywords: Critical Discourse Analysis, Racial Riots, and Political Messages 


\section{A. Latar Belakang}

\begin{abstract}
Demonstrasi yang berakhir dengan kerusuhan rasial anarkis beberapa waktuyang lalu terjadi di berbagai wilayah Papua dan Papua Barat. Kerusuhan rasial tersebut dipicu oleh kekecewaan masyarakat Papua terhadap insiden pengepungan asrama mahasiswa Papua di Surabaya oleh aparat keamanan, dan menyusul merebaknya isu pelecehan terhadap bendera Merah-Putih. Sebelumnya ada beberapa protes dari berbagai elemen masyarakat yang menganggap mahasiswa dari Papua tidak menghargai momen pada hari kemerdekaan Indonesia yang dilakukan oleh mahasiswa Papua yang bertempat tinggal di asrama Papua Jalan Kalasan, Surabaya, Jawa Timur.
\end{abstract}

Aksi demo rusuh diberbagai daerah Papua bukan yang awalnya didorong oleh adanya penangkapan mahasiswa papua oleh Polrestabes Surabaya tersebut berubah semakin menjadi-jadi setelah munculnyan banyak berita dan informasi yang kurang bisa dipertanggung jawabkan bertebaran di media sosial. Berita bohong "HOAX" yang beredar, memberitakan mahasiswa Papua ditangkap paksa oleh Polrestabes Surabaya, meninggal ketika adanya serbuan masa ke dalam asrama mahasiswa Papua, adanya persekusi, intimidasi serta perlakuan kasar yang dilakukan ormas-ormas dan oknum aparat. 'Bumbu-bumbu informasi' yang gencar ini yang membuat aksi demo menjadi rusuh dan banyaknya masyarakat Papua dan Papua Barat turun ke jalan. Pemblokiran jalan, bakar ban, fasilitas umum di rusak, bahkan pembakaran kantor DPRD Papua Barat di Manokwari juga menyertai aksi demo di Papua Barat.

Pemerintah tidak tinggal diam. Menyikapi banyaknya berita-berita yang dianggap memicu dan memanaskan situasi di Papua dan Papua barat, Pemerintah melalui Kementrian KOMINFO membatasi akses internet, karena di duga melalui jalur internet berita-berita sumir yang belum pasti kebenarannya menambah panas suasana di Papua dan Papua barat. Menurut Kem-KOMINFO, terdapat 270.000 kanal berita bohong atau hoax yang bertebaran di media sosial terkait rusuh di Papua, yang isinya mayoritas konten yang disebar di dunia maya bertentangan dengan hukum, antara lain, memprovokasi, menghasut, bahkan mengadu domba (sumber Tribunenews). Pemerintah akhirnya membatasi akses internet di Papua dan Papua Barat. Namun yang dibatasi hanyalah data 
internet, sementara SMS dan telepon tidak dibatasi.

Presiden selaku Kepala Negara meminta jajarannya untuk dapat menyelesaikan permasalahan rusuh Papua. Dalam rapat terbatas guna menyelesaikan konflik Papua, Presiden meminta kepada bawahannya agar situasi keamanan di Papua dijaga dan cepat dipulihkan, karena semua warga negara tanpa terkecuali harus dilindungi harkat dan martabat dan kerusakan umum segera diperbaiki sehingga aktivitas publik. Demi menarik perhatian warga Papua, Presiden Republik Indonesia mengundang para pemangku adat, tokoh masyarakat dan tokoh agama di Papua ke Istana Negara.

Dalam menyelesaikan konflik yang berkelanjutan di Papua, Presiden Jokowi melakukan beberapa strategi dalam menarik perhatian masyarakat Papua. Presiden meminta jajaran dan bawahannya untuk menjaga dan menghargai masyarakat Papua, serta memulihkan fasilitas umum yang terkena dampak dari aksi demo tersebut, kedua dengan mengundang dewan adat Papua untuk bermusyawarah dan mengemukakan aspirasi serta pendapat, dan yang ketiga melalui pernyataanpernyataan yang memberikan rasa damai terhadap rakyat dan masyarakat Papua.
Presiden juga mencoba membuat kondisi Papua menjadi lebih kondusif dengan membuat pernyataan resmi yang menyatakan keprihatinan dan permintaan maaf atas kejadian yang terjadi. Melalui beberapa kali pernyataannya ketika dikonfirmasi oleh para wartawan kepresidenan, Presiden Jokowi yang mengajak masyarakat Papua untuk dapat menahan emosi, dan tidak melakukan aksi demo anarkis sembari menekankan bahwa kita semua adalah saudara dan setanah air. Berikut merupakan salah satu pernyataan resmi Presiden Jokowi dalam menyikapi rusuh di Papua dan Papua Barat:

'Bapak ibu, saudara-saudara sebangsa dan setanah air, saya terus mengikuti perkembangan yang ada ditanah Papua dan Alhamdulillah situasi sudah berjalan normal kembali, pemintaan maaf sudah dilakukan dan ini menunjukan kebesaran hati kita bersama untuk saling menghormati, tuk saling menghargai sebagai saudara sebangsa dan setanah air. Saya juga telah memerintahkan kepada Kapolri untuk menindak secara hukum tindakan diskriminasi ras dan etnis yang rasis secara tegas, ini tolong digaris bawahi!!, dan minggu depan saya juga akan mengundang para tokoh dari Papua dan Papua Barat baik tokoh adat, tokoh masyarakat, tokoh agama untuk datang ke Istana berbicara masalah 
percepatan kesejahteraan di tanah Papua. Saya rasa itu yang bisa saya sampaikan pada sore hari ini, terima kasih".

Menariknya, pernyataan tersebut tidak serta merta meredakan situasi dan bahkan dianggap tidak cukup. Banyak pihak melihat pidato Presiden Jokowi tidak lebih dari sekedar simplifikasi masalah yang sebenarnya sangat besar karena menyangkut kedaulatan negara. Banyak pihak mengkritik pernyataan tersebut justru menunjukkan Jokowi tidak memahami persoalan yang terjadi. Akibatnya, kerusuhan terus terjadi dengan berbagai skala di beberapa daerah di Papua dan Papua Barat.

Peneliti tertarik untuk melihat lebih spesifik isi pidato Presiden Jokowi terkait dengan kerusuhan di Papua dan Papua Barat. Peneliti mencoba menelaah pernyataan presiden tersebut dengan menggunakan analisis wacana kritis Fairclaugh untuk melihat struktur pesan dan makna

\section{B. Tinjauan Pustaka}

\section{B.1. Pesan Politik}

Penelitian ini termasuk dalam ranah komunikasi politik yang merupakan salah satu kajian yang dipelaari dalam ilmu komunikasi.
Komunikasi Politik sendiri terdiri dari dua unsur kata yang berbeda yaitu 'komunikasi' yaitu sesuatu yang dilakukan oleh manusia atau individu dalam kehidupannya untuk memberikan pesan berupa informasi kepada individu lainnya dan 'politik' yang dapat didefinisikan sebagai suatu usaha yang ditempuh oleh warga negara untuk berdiskusi dan mewujudkan tujuan bersama.

$$
\text { Menurut }
$$

Mueller

(1973), Komunikasi Politik didefinisikan sebagai hasil yang bersifat politik apabila menekankan pada hasil. Sedangkan definisi Komunikasi Politik jika menekankan pada fungsi komunikasi politik dalam sistem politik, adalah komunikasi yang terjadi dalam suatu sistem politik dan antara sistem tersebut dengan lingkungannya. Dalam melakukan komunikasi politik, tentu hal yang tidak bisa dilupakan yaitu pesannya atau yang biasa disebut sebagai pesan politik. Pesan politik merupakan salah satu unsur penting dalam komunikasi politik. Pada hakikatnya, pesan adalah suatu informasi yang disampaikan oleh komunikator kepada komunikan yang bertujuan untuk mencari persamaan makna atau persepsi. Pada dasarnya, pesan berisikan gagasan atau ide manusia untuk disampaikan bahkan 
untuk diperbincangkan dengan manusia lain.

Davis V. J. Bell (Dan Nimmo, 2005-75), mengatakan bahwa sedikitnya ada tiga jenis kepentingan pembicaraan yang mempunyai kepentingan politik yang pasti dan jelas sekali politis dan merupakan pesan politik yaitu: tetang kekuasaan, pengaruh, dan otoritas. Pertama, kekuasaan, menyakut persoalan bagaimana mempengaruhi orang lain dengan ancaman atau janji. Kunci pembicaraan kekuasaan ialah kemampuan untuk mendukung janji maupun ancaman. Maka sebenarnya janji, ancaman, penyuapan dan pemerasan adalah alat tukar pada komunikasi dalam kepentingan kekuasaan. Kedua, kepentingan pengaruh. Kepentingan ini berkaitan dengan upaya memanipulasi persepsi ataupun harapan orang lain tanpa sanksi-sanksi. Di sini komunikator bisa memanfaatkan prestise atau reputasinya untuk mempengaruhi kemungkinan orang lain melalui nasihat, dorongan, permintaan, peringatan dan lain-lain. Sedangkan yang ketiga, kepentingan otoritas atau pemberian perintah. Yang dianggap sebagai penguasa yang sah adalah yang memiliki otoritas dan memiliki hak untuk mempengaruhi.

\section{B.2. Analisis Wacana Kritis Norman Fairclough}

Fairclough melihat bagaimana penempatan dan fungsi bahasa dalam hubungan sosial khususnya dalam kekuatan dominan dan ideologi. Faiclough berpendapat bahwa analisis wacana kritis adalah bagaimana bahasa menyebabkan kelompok sosial yang ada bertarung dan mengajukan ideologinya masing-masing.

Dalam melakukan analisis wacana kritis, Norman Fairclough menenakankan pentingnyta seorang peneliti untuk melihat teks sebagai hal yang memiliki konteks baik berdasarkan "process of production" atau "text production"; "process of interpretation" atau "text consumption" maupun berdasarkan praktik sosiokultural. Dengan demikian, untuk memahami wacana (naskah/teks) peneliti tak dapat melepaskan dari konteksnya. Untuk menemukan "realitas" di balik teks kita memerlukan penelusuran atas konteks produksi teks, konsumsi teks, dan aspek sosial budaya yang mempengaruhi pembuatan teks. Ini menegaskan bahwa sebuah teks tidak lepas dari kepentingan yang bersifat subjektif (subyektivitas).

Analisis wacana kritis

Fairclough sering dikatakan sebagai 
model perubahan sosial (social change) yang memusatkan pada perhatian wacana bahasa, dan digunakan sebagai alat praktik sosial diatas aktivitas individu atau merefleksikan sesuatu (Eryanto, 2001:286). Fairclough juga mengatakan bahwa wacana bahasa sebagai praktik sosial dan mengandung implikasi sebagai berikut:

1. Wacana adalah bentuk dari tindakan Seseorang menggunakan bahasa sebagai suatu tindakan pada dunia dan khususnya sebagai representasi ketika melihat realita dunia, dan menolak bahasa sebagai bentuk individu.

2. Adanya hubungan timbal balik antara wacana dengan struktur sosial Wacana terbagi oleh struktur sosial, kelas, dan relasi sosial lain yang dihubungkan dengan relasi spesifik dari institusi tertentu seperti pada buku, pendidikan, sosial dan klasifikasi.

Konsep ini mengasumsikan dengan melihat praktik wacana bisa jadi menampilkan efek sebuah kepercayaan (ideologis) artinya wacana dapat memproduksi hubungan kekuasaan yang tidak imbang antara kelas sosial, lakilaki dan wanita, kelompok mayoritas dan minoritas dimana perbedaan itu direpresentasikan dalam praktik sosial. Analisis Wacana melihat pemakaian bahasa tutur dan tulisan sebagai praktik sosial. Praktik sosial dalam analisis wacana dipandang menyebabkan hubungan yang saling berkaitan antara peristiwa yang bersifat melepaskan diri dari sebuah realitas, dan struktur sosial.

Dalam analisis wacana kritis, Fairclough memberikan perhatian yang sangat besar terhadap bagaimana melihat "bahasa sebagai praktik kekuasaan” (Eryanto, 2001: 285). Melihat bahasa dalam perspektif ini membawa konsekuensi tertentu, karena bahasa secara sosial dan historis adalah bentuk tindakan dalam hubungan dialektik dengan struktur sosial. Maka itu analisis harus dipusatkan pada bagaimana Bahasa itu terbentuk dan dibentuk dari relasi sosial dan konteks sosial tertentu (Fairclough, 1998-131132).

Menurut Norman fairclough (Eriyanto, 2011), analisis wacana kritis dibagi dalam tiga dimensi, seperti:

1. Analisis Mikrostruktur (Teks): menganalisis teks dengan cermat dan teliti, baik secara tertulis maupun lisan (linguistik). Serta memasukan koherensi dan kohesivitas, bagaimana kalimat digabung sehingga membentuk pengertian. 
Penganalisis-an ini guna melihat tiga masalah, yaitu:

a. Ideasional yang merujuk pada representasi teks, yaitu bagaimana peristiwa, orang, kelompok, situasi atau keadaan yang ditampilkan, umumnya bermuatan ideologi.

b. Relasi, merujuk bagaimana konstruksi hubungan antara wartawan dengan pembaca (apakah teks disampaikan secara tertutup atau terbuka, informal atau formal).

c. Identitas, merujuk pada konstruksi tertentu dari identitas wartawan dan pembaca, serta bagaimana personal dan identitas ini hendak ditampilkan.

2. Analisis

Mesostruktur (Discourse Practice) terfokus pada dua aspek yaitu produksi teks dan konsumsi teks. Teks dibentuk melalui Pratik diskursus yang melibatkan bagaimana hubungan antara komunikator dan komunikan, yang pada akhirnya akan menentukan bagaimana teks tersebut diproduksi. Fairclough mengemukakan bahwa analisis kewacananan berfungsi untuk mengetahui proses produksi, penyebaran, dan penggunaan teks. Dengan demikian, ketiga tahapan tersebut mesti dilakukan dalam menganalisis dimensi kewacanan.

3. Analisis Makrostruktur (Sociocultural Practice) terfokus pada dimensi yang berhubungan dengan konteks diluar teks, memang tidak berhubungan langsung dengan produksi teks,tetapi dapat menentukan bagaimana teks diproduksi dan dipahami.

Gambar 1. Analisis wacana kritis Fairclough.

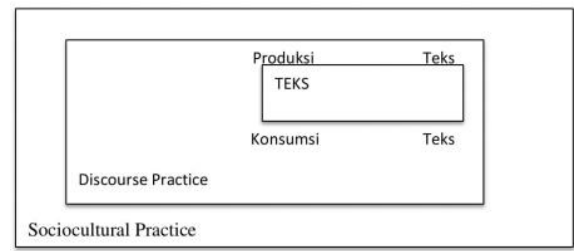

Sumber: Eriyanto, 2001

Dengan demikian, dalam metodenya Norman Fairclough berusaha menghubungkan antara analisis teks 
pada level mikro dengan konteks sosial yang lebih besar, dalam hal ini sociocultural practice. Dalam menganalisis metode Norman Fairclough ini, ketiga tahapan itu dilakukan secara bersama-sama. Seperti dalam Eriyanto (2001:326) bahwa analisis teks bertujuan mengungkap makna, dan bisa dilakukan di antaranya dengan menganalisis bahasa dengan kritis, sementara discourse practice mengantarai teks dengan konteks sosial budaya (sociocultural practice). Intinya bahwa hubungan antara sosial budaya dengan teks bersifat tidak langsung, yang kemudian disambungkan dengan discourse practice.

\section{Metodologi Penelitian}

\section{C.1 Prosedur Penelitian}

Penelitian ini merupakan penelitian dengan paradigma kritis terlahir dari pemikiran sekolah Frankfurt, Jerman pada masa perang dunia I. Paradigma kritis menjadi salah satu perlawanan secara ilmiah terhadap pemerintahan Hitler, dimana media menjadi alat pemerintah dalam mengontrol publik. Menurut Everett M. Roger saat itu, media sudah menjadi suatu entitas yang tidak netral, tetapi dapat dikuasai oleh kelompok dominan. Sementara menurut Sindhunata, pernyataan utama dari paradigma kritis adalah adanya kekuatan-kekuatan yang berbeda dalam masyarakat yang mengontrol proses komunikasi (Eriyanto 2001: 23,24).

Paradigma kritis merupakan suatu upaya untuk melihat secara dekat bagaimana makna pesan yang diorganisasikan, digunakan, dan dipahami. Dalam ranah politik, analisis wacana kritis merupakan suatu praktek pemakaian bahasa, terutama politik bahasa. Karena bahasa merupakan aspek sentral dari penggambaran suatu subjek, dan lewat bahasa ideologi terserap di dalamnya, maka aspek inilah yang dipelajari dalam analisis wacana kritis.

Paradigma kritis memandang bahwa realitas kehidupan sosial bukanlah merupakan suatu hal yang netral. Realitas kehidupan sosial dipengaruhi oleh berbagai kekuatan seperti politik, ekonomi, dan sosial. Konsentrasi analisis pada paradigma kritis adalah menemukan kekuatan yang dominan tersebut dalam memarjinalkan dan meminggirkan kelompok-kelompok yang lain, yang tidak dominan. Bahasa dalam wacana kritis dipandang sebagai representasi yang membentuk subjek, tema, maupun ideologi tertentu. Analisis wacana kritis memandang bahasa sebagai faktor yang penting, bahasa tersebut digunakan dalam melihat 
ketimpangan kekuasaan yang terjadi di masyarakat.

Objek yang menjadi penelitian ini adalah pernyataan Presiden Jokowi tentang kerusuhan rasial di Papua dan Papua Barat pada 19 agustus 2019, yang mengakibatkan banyaknya kerugian secara material dan psikologis masyarakat Papua dan papua Barat.

\section{C.2. Pengembangan Instrumen} Penelitian

Untuk menelaah obyek penelitian, peneliti menggunakan metode analisis wacana kritis (critical discourse analisis) yang dikembangkan oleh Norman Fairclough yang terbagi menjadi tiga dimensi, yaitu analisis wacana mikrostruktur (teks), analisis wacana mesostruktur, dan analisis wacana makrostruktur. Analisis wacana kritis ini fokus pada sifat alami kontekstualisasi ideologi yang memperhatikan efeknya terhadap bentuk dan makna, serta struktur wacana yang kelak berperan untuk membentuk dan mentransformasikan ideologi. Analisis wacana kritis dapat menampilkan efek ideologi, praktek sosial melalui pemakaian bahasa baik tutur kata maupun tulisan atau teks yang menyebabkan adanya hubungan dialeksis antara situasi, peristiwa deskriptif dengan situasi dan struktur sosial yang membentuknya. Hubunganhubungan produksi, reproduksi kekuasaan yang tidak seimbang, antara kelas sosial, laki-laki dan perempuan, mayoritas dan minoritas melalui perbedaan representasi sosial yang ditampilkannya.

Analisis wacana kritis Fairclough, sering dikatakan sebagai model perubahan sosial (social change). Memusatkan pada perhatian wacana bahasa, dan digunakan sebagai alat praktik sosial diatas aktivitas individu atau merefleksikan sesuatu (Eryanto, 2001:286). Hal ini dikarenakan, menurut Fairclough, wacana bahasa sebagai praktik sosial dan mengandung implikasi seperti wacana merupakan bentuk dari tindakan, seseorang menggunakan bahasa sebagai suatu tindakan pada dunia dan khususnya sebagai representasi ketika melihat realita dunia, dan menolak bahasa sebagai bentuk individu. Adanya hubungan timbal balik antara wacana dengan struktur social, wacana terbagi oleh struktur sosial, kelas, dan relasi sosial lain yang dihubungkan dengan relasi spesifik dari institusi tertentu seperti pada buku, pendidikan, sosial dan klasifikasi (Yoce Aliah, 2009:89). Untuk itu, peneliti akan menggunakan instrumen penelitian yang dikembangkan oleh Fairclaugh yang 
meliputi tiga level analisis, yaitu teks, discourse practise, dan social practise.

\section{Hasil dan Pembahasan}

\section{D.1. Analisis Teks}

Pada dasarnya analisi merupakan studi tentang struktur bahasa yang diproduksi dalam sebuah "discursive event" atau proses pewacanaan (Mirzaee \& Hamidi, 2012, p. 188). Yang dimaksudkan dengan "teks" sendiri tidak hanya bicara tentang fitur linguistik saja (klausa dan kalimat), tetapi juga bisa berupa gambar, suara, warna dan nyanyian dan sebagainya (Turhan \& Okan, 2017, p. 217). Norman Fairclaugh berpendapat bahwa untuk menganalisis sebuah teks ada tiga elemen penting yang harus dilihat, yaitu: representasi, hubungan dan identitas (Eriyanto, 2001, p. 289).

\section{Representasi}

Representasi dapat dilihat melalui tiga tingkatan: representasi pada anak kalimat, representasi dalam kombinasi anak kalimat, dan representasi dalam rangkaian anak kalimat.

a) Representasi dalam Anak Kalimat Menurut Fairclough, representasi dalam anak kalimat berkaitan dengan bagaimana seseorang, grup, acara, dan aktivitas ditampilkan dalam teks atau dalam kalimat yang diucapkan oleh seseorang. Penggunaan bahasa dapat dilihat dari pilihan kosa kata dan tata bahasa yang digunakan (Eriyanto, 2001, p. 290). Dalam hal ini, bagaimana seseorang, group, acara dan aktivitas diucapkan oleh Presiden Joko Widodo. Dalam pernyataannya soal Papua, Presiden Jokowi menyebut beberapa representasi dalam anak kalimat.

Kalimat pertama berbunyi:

'Bapak ibu, saudara-saudara sebangsa dan setanah air, saya terus mengikuti perkembangan yang ada ditanah Papua dan Alhamdulillah situasi sudah berjalan normal kembali, pemintaan maaf sudah dilakukan dan ini menunjukan kebesaran hati kita bersama untuk saling menghormati, tuk saling menghargai sebagai saudara sebangsa dan setanah air.

Pemilihan kosakata yang selektif tampak sekali pada kalimat pertama Presiden Jokowi. Terdapat beberapa kata yang ingin ditekankan pada pewacanaan ini. Frasa "mengikuti perkembangan" sengaja dipilih oleh Presiden Jokowi untuk menunjukkan bahwa dirinya tidak cuek dan diam terkait perkembangan situasi di Papua. Presiden memantau 
terus kejadian di Papua dari waktu ke waktu. Frasa "saudara sebangsa dan setanah air" dipilih untuk menunjukkan bahwa tidak ada perbedaan antara orang Papua dengan masyarakat lain di Indonesia. Hal itu diberikan tekanan dengan menambahkan kata "saudara" sehingga menonjolkan ikatan dekat bukan perbedaan. Frasa "saudara sebangsa dan setanah air", dipilih untuk memberikan penekanan kesamaan dan ikatan yang kuat bagi semua suku dan ras yang ada di indonesia.

Kata tanah Papua menunjukkan lokasi kerusuhan yang memeng terjadi dan menimbulkan keprihatinan bersama. Tanah Papua dipilih untuk melokalisasi dampak yang mungkin muncul dari perselisihan ras yang terjadi. Hal ini secara khusus dilakukan untuk menunjukkan bahwa yang terjadi persoalan diskrimanasi ras dan etnis hanyal di Papua, tidak di tempat lain di Indonesia. Kalimat kemudian dilanjutkan dengan kata "alhmadulillah", sebuah idiom bahasa arab yang didopsi dalam bahasa Indonesia dengan makna ungkapan puji syukur. Bila rasa syukur sudah diucapkan, berarti persoalan atau hambatan telah berhasil diatasi.

Berikutnya, Presiden Jokowi memilih kata "normal kembali" untuk menggambarkan kondisi di tanah Papua. Yang menarik, presiden tidak memilih kata sudah aman atau kata lainnya yang menggambarkan pulihnya kondisi keamanan di Papua. Kata normal berarti menurut aturan atau menurut pola yang umum. Kondisi menjadi sesuai dan tidak menyimpang dari suatu norma atau kaidah; sesuai dengan keadaan yang biasa; tanpa cacat. Dengan demikian Presiden ingin menekankan pulihnya kondisi di Papua karena kembali sesuai dengan norma atau aturan yang ada. Meskipun sebenarnya, kondisi ini tidak menjamin keamanan. Artinya, normal belum tentu aman.

Frasa berikutnya adalah “permintaan maaf”. Permintaan maaf menunjukkan kerelaan hati seorang pelaku mengakui kesalahan yang dilakukan. Ada juga kebesaran hati, saling menghormati, saling menghargai yang menunjukkan perilaku mulia yang menunjukkan kualitas diri seorang warga bangsa. Kata-kata tersebut dipilih Presiden Jokowi untuk menunjukkan 
kemuliaan kita sebagai sesama warga bangsa bila melakukannya.

Kalimat kedua berbunyi:

'Saya juga telah memerintahkan kepada Kapolri untuk menindak secara hukum tindakan diskriminasi ras dan etnis yang rasis secara tegas, ini tolong digaris bawahi!!”

Pada kalimat tersebut terdapat kata memerintahkan Kapolri, yang menunjukkan telah memberikan otoritas kepada kapolri untuk melakukan segala sesuatu yang diperlukan. Melalui pemilihan kata ini, menunjukkan bahwa presiden tidak tinggal diam atau sengaja membiarkan. Ia telah memberi perintah kepada Kapolri untuk melakukan sesuatu. Menarik untuk dianalisis bahwa yang diperintah adalah kapolri, bukan panglima TNI. Ini menunjukkan bahwa meskipun terjadi kerusuhan, Papua masih dalam kontrol negara karena masih dalam ranah tertib sipil yang tidak mengganggu stabilitas nasional. Maka yang diperintah Kepala Kepolisian bukan Panglima TNI. Perintah kepadan Panglima hanya akan muncul ketika negara dalam keadaan terancam kedaulatannya.

Frase berikutnya yang ada adalah "menindak secara hukum" yang digunakan untuk menunjukkan tindakan yang dilakukan Kapolri harus sesuai dengan hukum yang berlaku. Bukan tindakan serampangan, sembarangan tanpa mempedulikan hukum dan aturan yang berlaku. Presiden sepertinya ingin menunjukkan keberadaan Indonesia sebagai negara hukum, dimana hukum adalah panglimanya. Tindakan tegas yang diambil oleh kepolisian adalah tindakan terukur yang sesuai dengan undang-undang.

Frase berikutnya adalah "tindakan diskriminasi ras dan etnis". Frase ini menunjukkan adanya tindakan diskriminasi ras dan etnis yang buruk dan perlu ditindak secara tegas. Tindak diskriminasi adalah tindakan yang tidak terpuji yang bisa menyebabkan bangsa terpecah belah. Hal ini perlu ditindak karena Indonesia terdiri dari banyak ras dan etnis sehingga bila terjadi tindakan diskriminasi, kesatuan dan persatuan bangsa akan terancam.

Frase berikutnya adala "tolong digaris bawahi" yang menunjukkan pentingnya pesan Jokowi tersebut. Presiden mau menunjukkan bahwa dirinya sangat consern dengan persoalan tersebut sehingga meminta semua pihak 
untuk memperhatikan hal tersebut. Presiden ingin menunjukkan bahwa persoalan tindakan diskriminasi ras dan etnis merupakan persoalan penting dan perlu penanganan yang tegas sesuai dengan koridor hukum yang berlaku.

Kalima berikutnya berbunyi:

"Dan minggu depan saya juga akan mengundang para tokoh dari Papua dan Papua Barat baik tokoh adat, tokoh masyarakat, tokoh agama untuk datang ke Istana berbicara masalah percepatan kesejahteraan di tanah Papua”.

Kata "minggu depan" menunjukkan keterangan waktu satu minggu lagi yang mengandung arti tidak akan lama lagi. Dalam kalimat tersebut terdapat frase "tokoh masyarakat Papua dan Papua Barat" yang merepresentasikan orang-orang yang dipercaya atau mewakilkan suara masyarakat Papua dan Papua Barat. Mereka akan diundang Presiden Jokowi ke istana negara. Diundang ke istana negara berarti diundang ke sebuah tempat yang merepresentasikan pusat pemerintahan atau pusat kekuasaan. Jokowi menyebut tokoh adat, tokoh masyarakat dan tokoh agama Papua dan Papua Barat, menunjukkan bahwa dirinya ingin mendengar suara dari masyarakat yang mewakilkan Papua secara langsung. Ketiga kelompok tokoh tersebut saat ini memang mewakilkan masyarakat Papua dan Papua Barat. Mereka sangat menghormati tokoh adat, tokoh agama, dan pemimpin masyarakat.

Frase berikutnya adalah "percepatan kesejahteraan di tanah Papua". Frase tersebut terdiri dari tiga suku kata, yaitu percepatan yang berarti usaha untuk membuat lebih cepat, kesejahteraan yang berarti kondisi masyarakat yang sejahtera, dan tanah Papua yang menunjukkan lokasi dimana kesejateraah itu perlu dipercepat. Melihat kombinasi tiga suku kata tersebut, berarti saat ini kesejahteraan di tanah Papua masih masih sangat rendah atau masih berlangsung sangat lamban sehingga perlu dipercepat. Pemilihan frase tersebut menunjukkan bahwa sebagai presiden, Joko Widodo ingin mengetahui persoalan utama dari lambatnya kesejahteraan di tanah Papua. Ia merasa diperlukan upayaupaya percepatan maka mengundang tokoh-tokoh masyarakat Papua dan Papua Barat ke Istana.

Kalimat terakhir berbunyi: 
"Saya rasa itu yang bisa saya sampaikan pada sore hari ini, terima kasih",

b) Representasi dalam Kombinasi

Anak Kalimat

Kombinasi anak kalimat membentuk koherensi lengkap tentang ideologi pencipta teks. Presiden Jokowi mencoba menunjukkan kepeduliannya tentang masalah diskriminasi ras dan etnis yang terjadi di Papua. Hal ini terlihat dalam kombinasi anak kalimat berikut:

"Saya terus mengikuti
perkembangan yang ada
ditanah Papua",

Selain itu, Presiden Joko Widodo juga mengedepankan pentingnya saling menghormati dan menghargai sebagai sesama saudara sebangsa dan setanah air. Pernyataan itu dikombinasikan dengan rasa syukurnya bahwa kondisi tanah Papua sudah mulai normal kembali karena permintaan maaf juga telah dilakukan oleh mereka yang terlibat. Hal itu terlihat dalam kombinasi anak kalimat berikut:

"Alhamdulillah situasi sudah berjalan normal kembali, pemintaan maaf sudah dilakukan dan ini menunjukan kebesaran hati kita bersama untuk saling menghormati, tuk saling menghargai sebagai saudara sebangsa dan setanah air".

Kombinasi anak kalimat berikut ini menunjukkan bagaimana komitmen Pemerintah terhadap masalah penegakan hukum yang akan dilakukan oleh pemerintah. Presiden menegaskan bahwa pemerintah akan menindak secara tegas dan sesuai dengan koridor hukum terhadap para pelaku diskriminasi ras dan etnis yang terjadi di Papua. Komitmen pemerintah tersebut terepresentasikan dalam kombinasi anak anak kalimat ini:

"Saya juga
memerintahkan telah
Kapolri untuk menindak
secara hukum tindakan
diskriminasi ras dan etnis
yang rasis secara tegas, ini
tolong digaris bawahi!!"

Untuk menunjukkan bahwa Pemerintah sangat memperhatikan persoalan Papua, Presiden Jokowi mengatakan bahwa pemerintah telah bertekad mempercepat kesejahteraan rakyat Papua. Kombinasi anak kalimat berikut menunjukkan bagaimana tekad pemerintah untuk mendengar masyarakat Papua 
sehingga bisa mempercepat penciptaan kesejahteraan di tanah Papua.

"Dan minggu depan saya juga akan mengundang para tokoh dari Papua dan Papua Barat baik tokoh adat, tokoh masyarakat, tokoh agama untuk datang ke Istana berbicara masalah percepatan kesejahteraan di tanah Papua."

c). Representasi dalam Rangkaian Anak Kalimat

Dalam pernyataan singkat Presiden Jokowi tentang kekerasan rasial di tanah Papua tersebut, terdapat beberapa rangkaian anak kalimat yang (bila dianalisis secara mendalam) memiliki koherensi dan secara tidak langsung menunjukkan atau menegaskan kembali ideologi negara. Beberapa anak kalimat mewakili aspek-aspek dalam kehidupan bernegara, yaitu:

i. Aspek penegakan hukum

Aspek ini tampak nyata dalam rangkaian anak kalimat:

“ Saya juga telah memerintahkan kepada Kapolri untuk menindak secara hukum tindakan diskriminasi ras dan etnis yang rasis secara tegas, ini tolong digaris bawahi!!" ii. Aspek kesetaraan sebagai anak bangsa

Aspek ini tampak nyata dalam rangkaian anak kalimat:

“... pemintaan maaf sudah dilakukan dan ini menunjukan kebesaran hati kita bersama untuk saling menghormati, tuk saling menghargai sebagai saudara sebangsa dan setanah air".

iii. Aspek kesejahteraan Aspek ini tampak dalam kalimat:

"Dan minggu depan saya juga akan mengundang para tokoh dari Papua dan Papua Barat baik tokoh adat, tokoh masyarakat, tokoh agama untuk datang ke Istana berbicara masalah percepatan kesejahteraan di tanah Papua."

\section{Hubungan}

Elemen hubungan atau relasi berkaitan dengan keberadaan Presiden Joko Widodo sebagai representasi dari pemerintah atau lembaga eksekutif yang mempunyai kewenangan untuk mengatur pemerintahan Negara Kesatuan Republik Indonesia dengan seluruh rakyat Indonesia. Presiden Jokowi berupaya memberikan rasa tenang dan menciptakan suasana yang kondusif di tengah konflik yang sedang 
melanda provinsi paling ujung timur Indonesia tersebut. Penonjolan frase "sudah berjalan normal kembali" untuk menjelaskan kondisi terakhir di Papua, Jokowi seakan berusaha menenangkan seluruh masyarakat Indonesia untuk tenang kembali dan tidak perlu takut atau khawatir.

Jokowi menempatkan dirinya sebagai pihak yang selalu memperhatikan dan mengikuti segala perkembangan yang terjadi di tanah Papua. Jokowi menegaskan tekadnya untuk terus memberikan waktunya untuk tanah Papua. Ia bertekad untuk mempercepat pembangunan dan menciptakan kesejahteraan di Papua. Sebagaimana diketahui, hingga saat ini, Jokowi adalah presiden Indonesia yang paling sering mengunjungi tanah Papua dibandingkan presiden lainnya.

Hubungan relasional semacam ini tentu saja mempunyai sisi yang positif karena presiden tidak menempatkan masyarakat Papua sebagai bawahan. Presiden juga tidak menunjukkan sikap marah, kasar dan mengecam pihak-pihak tertentu yang terlibat dalam diskriminasi ras dan etnis. Melainkan lebih menekankan kembalinya kehidupan normal masyarakat Papua sambil menegakkan hukum yang berlaku melalui kepolisian.
Sikap yang diambil Presiden Jokowi tersebut semakin mengukuhkan perhatian khusus Jokowi terhadap Papua selama ini. Presiden bahkan mengundang para tokoh adat, tokoh masyarakat dan tokoh agama dari Papua dan Papua Barat ke Istana Negara untuk berdialog mempercepat pembangunan kesejahteraan di Papua. Ini semakin meningkatkan relasi positif yang ada dan memberikan kesan yang positif juga bagi Presiden karena Pemerintah Jokowi menempatkan dirinya sebagai superstruktur tetapi sejajar dengan masayarakat adat, Gereja atau elemen lainnya di Papua.

\section{Identitas}

Pernyataan Presiden Joko Widodo mewakili identitasnya sebagai bagian dari masyarakat Indonesia karena beliau adalah presiden dari seluruh rakyat Indonesia. Sebagai orang Jawa, dalam beberapa kali memberikan pernyataan terkait dengan pemerintah, Presiden Jokowi memang selalu menunjukkan karakter yang hati-hati dalam menyampaikan pendapat. Memilih kata dengan cermat, tidak menggebu-gebu bahkan cenderung pelan namun lugas. Sebagaimana karakter orang Jawa, gaya pidato presiden Jokowi tidak meledak-ledak dan hampir tidak ada teriakan atau 
suaran yang keras. Gaya bahasan yang tampak dalam pidato atau pernyataan Jokowi menunjukkan identitas dirinya sebagai orang Jawa tulen.

\section{D.2. Praktik Wacana}

Analisis praktik wacana selalu fokus beberapa aspek penting yang meliputi: produksi, konsumsi, dan reproduksi teks (Mirzaee \& Hamidi, 2012, p. 188). Dalam hal ini, fokus yang dilihat meliputi pernyataan Joko Widodo tentang persoalan Papua sebagai teks dalam penelitian ini. Retorika tersebut kemudian diperiksa dari dua sisi: produksi teks (dengan melihat dari sisi Joko Widodo secara langsung) dan konsumsi teks (dengan mengamati respons publik terhadap pernyataan Joko Widodo).

Joko Widodo lahir 21 Juni 1961 di Surakarta, Jawa Tengah. Joko Widodo tumbuh dalam keluarga yang sederhana di Surakarta, bahkan pernah tinggal di pinggir kali. Bahkan pernah merasakan digusur hingga tiga kali dari bantaran sungai. Sejak kecil Jokowi hidup dengan sangat keras dalam keluarga berlatar belakang tukang kayu dan akhirnya berhasil menjadi pengusaha mebel terkenal di Surakarta. Setelah makan asam garam dunia perkayuan, Jokowi menjadi Walikota
Surakarta selama dua periode (20052012). Jokowi pernah menjabat sebagai Gubernur DKI Jakarta bersama dengan Basuki Tjahaja Purnama sebagai Wakil Gubernur sejak 15 Oktober 2012 hingga 16 Oktober 2014. Pada umur 58 tahun, Jokowi berhasil memenangi pemilihan Presiden Republik Indonesia bersama dengan Mohamad Jusuf Kalla sebagai Wakil Presiden di tahun 2014. Saat Ini Jokowi masih menjabat sebagai Presiden Republik Indonesia setelah memenangkan Pemilu Presiden 2019 bersama Kyai Ma'ruf Amin sebagai Wakil presiden.

Sebagai Presiden, Joko Widodo menyadari bahwa kesuksesan kepemimpinannya akan dilihat dari kemampuannya mengendalikan persoalan bangsa. Salah satu persoalan yang rentan menimpa Indonesia adalah perselisihan yang melibatkan persoalan SARA (suku, agama, ras dan antar golongan). Hal ini tidak lepas dari komposisi warga Indonesia yang memang terdiri dari berbagai suku, bangsa, agama, ras, dan terdiri dari berbagai golongan. Kesadaran Jokowi akan pentingnya menjaga persatuan dan kesatuan bangsa.

Pengalamannya menjadi kepala daerah (Walikota dan Gubernur) pada periode sebelumya, ikut mengasah cara kepemimpinan Jokowi yang tidak 
reaksioner atau meledak-ledak ketika menanggapi kasus kerusuhan rasial di Papua dan Papua Barat. Bahkan Jokowi terlihat cenderung "kalem" dalam menanggapi kerusuhan tersebut. Hal ini membuat banyak pihak yang bahkan berpendapat bahwa pemerintah tidak hadir di sana karena presiden dianggap terlalu lama memberikan statemen terkait kerusuhan yang terjadi.

Pernyataan yang dibuat oleh Joko Widodo sebenarnya merupakan rangkaian dari pernyataan singkat Jokowi sebelumnya tentang kericuhan Papua. Pernyataan tersebut merupakan cerminan dari serangkaian pengalaman hidup dan karier. Pengalamannya sebagai pengusaha dan pemimpin daerah mendorong dirinya untuk tidak terlalu cepat dan reaktif menanggapi persoalan yang sedemikian genting. Ia memilih untuk berhati-hati dalam menanggapi persoalan yang adan, memilih kata dan kapan harus menanggapinya. Bahkan dalam pernyataan tersebut ia tidak mengeluarkan kecaman terhadap kekerasan yang ada, tetapi lebih memilih untuk mendorong tindakan hukum yang sesuai dan pernyataan maaf yang telah dilakukan sebagai sesama anak bangsa. Dari keseluruhan pernyataan tersebut, Joko Widodo sepertinya ingin mengarahkan persoalan kekerasan ras yang terjadi ke persoalan ketimpangan kesejahteraan yang terjadi di Papua. Jokowi tidak memberikan penekanan pada kekerasannya, tetapi lebih menitikberatkan pada adanya kesenjangan kesejahteraan yang selama ini terjadi di Papua dan Papua Barat dibantingkan daerah lainnya di Indonesia.

Pada bagian rencana Jokowi untuk bertemu dengan tokoh adat, tokoh masyarakat, dan tokoh agama Papua untuk membicarakan percepatan kesejahteraan Papua dan Papua Barat, menyiratkan bahwa Jokowi memandang persoalan kesejahteraan merupakan solusi yang paling jitu untuk menyelesaikan konflik yang ada. Dalam pernyataan tersebut Jokowi tampak percaya bahwa persoalan kesejahteraan adalah akar persoalnya. Meskipun juga sempat menyinggung soal penegakkan hukum yang telah diperintahkan kepada Kapolri, persoalan percepatan kesejahteraan tetaplah menjadi titik berat yang ingin segera diselesaikan oleh Jokowi.

Sementara pada tingkat konsumsi teks, peneliti mencoba mengamati tanggapan masyarakat terhadap pernyataan tersebut. Beberapa penggiat HAM mengkritik pernyataan Jokowi terkait berbagai kebijakan Papua NTT yang cenderung mengkaitikan 
dengan persoalan kesejahteraan. Mereka juga mengkritik Jokowi karena selama ini memberikan fokus terlalu banyak pada persoalan ekonomi khususnya infrastruktur di Papua, sementara persoalan politik tidak diselesaikan.

\section{D.3. Praktik Sosiokultural}

Fairclough menjelaskan bahwa untuk menjelaskan praktek sosiokultural, ada tiga tingkatan analisis yang harus dilakukan, yaitu: analisis tingkat situasional, kelembagaan dan sosial (Eriyanto, 2001: 320-322).

1. Pada tingkat situasional, pernyataan Joko Widodo muncul karena kondisi masyarakat kerusuhan Papua yang menegangkan hingga menyebabkan puluhan orang meninggal dunia. Sebenarnya ini bukan pernyataan pertama Jokowi tentang kerusuhan Papua. Setidaknya peneliti mencatat ada dua lagi pernyataan sebelumnya tentang Papua, dimana Jokowi meminta masyarakat Papua untuk saling memaafkan dan berbesar hati.

2. Pada tingkat kelembagaan, Joko Widodo sebagai
Presdien mempunyai perhatian khusus terhadap Papua dan Papua Barat. Pemerintahan di bawah presdien Joko Widodo merupakan pemerintahan yang memberikan perhatian yang sangat besar di kedua provinsi di ujung itmur Indonesia tersebut. Bahkan Jokowi sangat rutin mengunjungi Papua dan Papua Barat selama periode pertama pemerintahannya. Ia juga mempunyai menteri dan tim kerja yang berasal dari Papua dan Papua Barat. Jokowi mempunyai tekad besar untuk memajukan Papua dan Papua Barat.

3. Pada level sosial, peneliti melihat secara khusus karakteristik masyarakat Papua dan Papua Barat. Kedua Provinsi yang mendiami satu pulau ini mempunyai dua jenis wilayah, yaitu wilayah pegunungan dan pesisir (pantai). Papua dan Papua Barat terdiri dari berbagai suku yang tersebar di seluruh pulau. Di antara suku-suku yang ada, tidak dijumpai 
peseteruan hingga perang antar suku. Berbeda dengan penduduk lain di sisi lain barat Indonesia yang merupakan ras mongoloid, penduduk asli Papua dan Papua Barat merupakan ras melanesia.

\section{E. Kesimpulan}

Dari analisis yang telah dilakukan diatas, dapat disimpulkan bahwa dibalik pernyataan Presiden Joko Widodo terkait kerusuhan rasial di Papua dan Papua Barat, presiden sebenarnya mewacanakan persoalan kesejahteraan yang tidak dinikmati masyarakat Papua dan Papua Barat sebagai biang keladi dari kerusuhan rasial yang terjadi. Presiden seorang ingin menggiring persoalan kerusuhan rasial di Papua dan Papua Barat, didorong oleh rasa ketidakpuasan masyarakat Papua dan Papua Barat terhadap pembangunan yang dilakukan pemerintah pusat. Dalam berbagai pernyataan sebelumnya, Presiden Jokowi tidak menyinggung sama sekali tentang persoalan politik yang sebenarnya terasa cukup "kental" mewarnai kerusuhan tersebut. Ia hanya menyinggung tentang penegakan hukum dan normalnya kondisi terkini di Papua dan Papua Barat.

Pada sisi yang lain, pewacanaan ini seakan "seiring dan seirama" dengan keprihatinan Jokowi sendiri (selama ini) tentang pembangunan di Papua dan Papua Barat yang memang sangat tertinggal. Seakan-akan apa yang diresahkan oleh masyarakat Papua, sebenarnya sudah "ditangkap" oleh Jokowi selama ini. Rencana untuk menemui para tokoh masyarakat, tokoh adat, dan tokoh agama Papua dalam rangka membicarakan percepatan pemerataan kesejahteraan di Papua dan Papua Barat, tersasa menjustifikasi pewacanaan tersebut. Apa yang diungkapkan Jokowi selama terjadi kerusuhan rasial di Papua dan Papua Barat, tidak lebih dari pembenaran untuk program-program Jokowi di Papua dan Papua Barat, termasuk tentang infrastruktur. Bila wacana tentang pentingnya infrastruktur untuk mengurangi ketertinggalan dan mempercepat kesejahteraan berhasil diwacanakan, tidak ada alasan lagi untuk tidak melakukannya.

\section{Daftar Pustaka}

Ardial. 2010. Komunikasi Politik. Jakarta: PT Indeks

Dan Nimmo. 2005. Komunikasi Politik. Bandung: PT Remaja Rosdakarya 
Darma, Yoce Aliyah. 2009. Analisis

Wacana Kritis. Bandung:

Yrama Widya.

Eriyanto. 2001. Analisis Wacana:

Pengantar Analisis Teks Media.

Yogyakarta: LkiS

Fairclough, N. 1998. Discourse representation in media discource, Sosiolinguistics. Cambridge : Polity Press.

Fairclough, N. 1992 Discource and Social Change, Cambride: Polity Press

Fairclough, Norman 2003. Analysis Discource. New York Routledge

Furchan Arief, 1992, Metode Penelitian Kualitatif, Usaha Nasional, surabaya

Gramsci, 1987, Selections From th Prison Notebooks, New York: International Publisher.

Hariman Siregar, 1994,Hati Nurani

Seorang Demosntran, Jakarta: Mantika

Media Utama

Henink, Monique, etc. 2011.

Qualitative Research Methods.

London: Sage

PublicationsJorgersen dan Phillips.2007. Feminist Critical Discourse Analysis and Children's Fantasy Fiction. Finland

Sanafiah Faisal, 1990, Penelitian Kualitaif: Dasar-Dasar dan Aplikasinya, Y3A, Malang
Littlejohn \& Foss, 2008. Theories of Human Comunication. Ninth Edition. Belmont-USA:

Thomson Wadsworth

McQuail, Dennis. 2005. Mass Communication Theory, Fifth Edition, London: SAGE Publications

Mirzaee, S. and Hamidi, H. (2012). Critical Discourse Analysis and Fairclough's Model. International Electronic Journal for the Teachers of English, 2. 182191

Sanafiah Faisal, 1990, Penelitian Kualitaif: Dasar-Dasar dan Aplikasinya, Y3A, Malang

\section{Web Site:}

- Detik detikNews / Berita / Detail BeritaFollow detikcom, Pesan Jokowi tentang Perlunya Memaafkan dalam Ketersinggungan 2019/08/19 19:49:13 WIB, diakses $12 / / 9 / / 2019$

- DetikNews / Berita / Detail BeritaFollow detikcom, Istana: Soal Kondisi Papua, Jokowi Imbau Semua Pihak Menahan Diri. Rabu 21 Agustus 2019, 18:09 WIB, diakses 12/9/2019 